\title{
A BRIEF REVIEW OF CHINESE CONTRIBUTIONS TO COMMUNICATION AND MEDIA STUDIES CHIEN-SAN FENG
}

\begin{abstract}
This article reviews contributions to communication and media studies originating in Taiwan and China during the past decade. While China has provided Chinese readers with a relatively rich critical literature in the media histories of advanced capitalist societies, this literature has been weak in providing discourses regarding China's own changing media political economy. In comparison, the situation in Taiwan has been quite the opposite. Here, reception of Western media history has been short on class perspective, while recent work has recorded and radically commented on the island's contemporary media politics of national identity, intellectual intervention, and Americanimperialism. This article also provides a brief review of English and Chinese literature which analyses Chinese media systems and communication practices in transition.
\end{abstract}

Chien-san Feng (FANG) is Professor at the Department of Journalism, Chengchi University, Taipei. 
Owing to very different historical processes during the past 50 years, ${ }^{1}$ ethnic Chinese in China, Taiwan and Hong Kong have developed distinguishable orientations and roles in the field of communication research. Inasmuch as Chinese academics in Hong Kong and some western countries write mainly in English and this work is readily available in various books to be mentioned shortly and in journals such as the Journal of Communication and Asian Journal of Communication, this essay will emphasise academic work written in Chinese and published in China and Taiwan. Academic theses and dissertations, and industrial and governmental reports will not be considered.

In the 1960s when the capitalist world economy went through its first wave of crisis since the end of World War II, China's self-reliance model of developing its economy and society had attracted attentions from many scholars investigating relationships between communication and development. One example of this is the edited volume by Chu and Hsu (1979) Moving A Mountain: Cultural Change in China. Contrary to what readers of this work might believe, this approach to communication studies has been less dominant during the past two decades. The socialist systems, including the one in China, have been exposed to more weaknesses during the past period than countries in the capitalist bloc. And, since the late Deng Xiaoping resumed power in 1984, China has opted for an open policy, and has ceased to be the exemplary case of an alternative mode of development. Although China claims nonetheless that its developmental route represents "socialism with Chinese characteristics," this assertion fails to hide the fact that China's Communist Party has, even when allowing economic reforms, full control over the system of mass commu-nications.

Since the 1989 student movement clamp-down, people have been looking closer at changing media systems and communication practices in China. Observers have been examining the degree to which China maintains a grip on political institutions (including the media) and, at the same time, encourages opening up the economy. On these issues, Chin-Chuan Lee has provided the English-speaking world a valuable service with three edited volumes: Voice of China: The Interplay of Politics and Journalism (1990); China's Media, Media's China (1994); and the forthcoming volume Money, Power, and Media: Communication Patterns, Bureaucratic Control in Cultural China. This last book also deals with Taiwan and Hong Kong. ${ }^{2}$

For scholars inside China, understandably and regrettably, this topic is not one on which they can supply empirical data or engage in theoretical discussions. Under current circumstances, academics in China can do little to enhance our knowledge about the transforming landscape of Chinese media systems. This stands in stark contrast to their efforts and achievements, especially since the mid-1980s, in providing us with rich writings on the historical evolution of media industries across a number of Western countries and Japan. Although not original, these works display two related features. First, they normally make extensive uses of literature from major European, American, Russian and Japanese languages and therefore provide a much broader range of data and arguments than commonly seen in English-language publications on similar topics. ${ }^{3}$ Second, these works are mostly the result of collective enterprises since the very scope they cover is too broad for individual scholars.

It has already been noted that contributions made by communication scholars in China, chiefly because of political constraints, are less valuable in understanding China's media ecology, and are better at providing critical perspectives on bourgeois media histories to Chinese readers. In contrast, work from Taiwan is strikingly weak 
in appreciating media histories, be that of its own or of other countries, from a critical or class angle. In recent years Taiwan has, however, produced a small number of works on contemporary media developments from liberal and radical perspectives. Since 1988, Taiwan's political, intellectual and media landscapes have undergone great turmoil. The number of television channels has increased from three to over 70 (including some 19 movie channels, while Taiwan produces less than 20 films per year); the generally docile campus has produced enough disobedient academics to challenge the authoritarian party-state; and the suppressed Taiwan identity has reasserted itself to the extent that civilian groups are waging campaigns for Taiwan's independence, a political position which risked the charge of treason and a death sentence until late 1992, but also defying China's policy of "One Country Two Systems" with a consequence of prompting China to take over Taiwan with military forces.

It is against such background that noteworthy contributions have been made and enriched the Chinese communication literature. Six titles published in Chinese and available mainly in Taiwan and Hong Kong will be reviewed: Boycotting the Newspaper to Sustain Taiwan's Independence (TPA 1993a, 1993b and 1994), Deconstructing Television and Broadcasting Media (Cheng 1993), Media Reform, Freedom and Democracy (Jiang 1994), For a Political Economy of Taiwan's Television and Broadcasting Industries in the 1990s (Feng 1995), Newsroom Democracy (MCR 1996), and From Postmodernism to Decolonization (Chen, forthcoming). These publications are categorised into three parts, starting from those of the Taiwan Professors Association (TPA) and of Chen (with themes on identity politics, newspapers and intellectuals). This is followed by the volumes edited by Cheng, Jiang and Feng (all concerned with radio and television policies, including cable and satellite) and ending with a special issue of the journal Mass Communication Research (documenting Taiwan's first street demonstration of journalists and its consequences). This review, it should be emphasised, is more descriptive than critical.

"At all cost and without the slightest fear of bloodshed, China would revert the course of economic reforms and wage war to prevent Taiwan from moving towards the direction of independence." On October 30, 1992, the United Daily News (UDN), the largest daily with a circulation over a million copies, placed this quotation from an interview with one of China's leaders on its front page. As one of two most influential newspapers, UDN's inclination towards unification with China has long been dissented by people with a strong Taiwanese identity. The newspaper had once been threatened with a bomb attack in the late 1970s, and this time, by its very deliberative and provocative coverage, the newspaper experienced a well co-ordinated boycott, effectively and actively organised by Taiwan Professors Association (TPA), a political group formed in 1990 by academic intellectuals across the island, one of its main objectives being to advocate for Taiwan's independence.

The full gamut of legal, political, economic and sociological arguments of this campaign, lasting for more than 18 months, is recorded and analysed in TPA's own booklets (1993a, 1993b and 1994). Though the sale of UDN newspapers did not experience any substantial drop (according to reports, a maximum of 80,000 copies were lost), the campaign unexpectedly brought about two democratic reforms to the press, especially to the UDN itself. Before this media reform movement was launched, Taiwan's newspapers did not allow readers to have regular access to space; there were only sporadic occasions when papers would print readers' opinions, and the space devoted to this purpose was never more than half a page. But starting from March 
1993, three months in the wake of TPA's campaign, UDN initiated Taiwan's first “Letters to the Editor" column and has since continued this practice daily. In retrospect, this new routine should be considered part of the strategy UDN adopted to boost its public image and thereby demonstrated its care for readers' right to express dissenting views. Since then, this letters-to-the-editor column has essentially been institutionalised in Taiwan, as many other newspapers rapidly followed suit.

Second, the conservatively oriented UDN has become more tolerant of liberal or even radical perspectives on social movements and related issues. In a survey conducted by the Mass Communication Research Centre at Chengchi University nearly two years after the boycott findings suggest that UDN had been providing more and conspicuous space to feminism, environmentalism and labour news. In addition, its viewpoints are often more progressive than its major competitor, the China Times, which has a more liberal outlook. Ironically, though, UDN's position regarding pro-unification has not changed to any degree. Given this, it is uncertain whether the UDN may be revamping other conservative images merely to defuse the people's anger at its position toward China.

The newspaper boycott indicated that Taiwan shares with several countries a common feature and dilemma: identity politics based on an ethnic group or geographic nation is a major force, particularly in comparison to identities based on class and gender. For a number of years, through work published in the English-language journal Cultural Studies and Position, but particularly through contributions in a forthcoming Chinese-language book, Kuan-hsin Chen has been making concerted efforts to argue for alternative or opposite identities. "The imperialist eye: the cultural imaginary of a sub-empire and a nation-state" (translated into Japanese in 1995), an essay in the book From Postmodernism to Decolonization, can be considered illustrative of the attention to identity politics. When it first appeared in 1994 in the radical quarterly Taiwan, the paper received widespread attention and generated heated rejoinders.

In early 1994 the media (including the China Times' widely read literary supplement) published warm receptions of the Taiwan state apparatus project of "marching southward," i.e., urging Taiwan's capital to invest in Southeast Asian countries, while at the same time avoiding investments in China since such investment is officially interpreted as benefiting the Communist regime and pushing Taiwan into the "enemy's" political sway. According to Chen's analysis, this represented is a unusual combination of fear, arrogance, negligence and deliberation. He further contends that it constituted a hegemonic project representing a "state/capital/male/racial/ethnic chauvinism," and disclosed a desire of formulating Taiwanese subimperialism directly copied from Japanese imperialist cultural history (Taiwan was colonised by Japan between 1895 and 1945). Chen argues that this project attempts to utilise the social forces emitted after the collapse of the authoritarian regime of the Nationalist Party which had full control prior to the 1990s. He subsequently elaborates how Communist China is constructed as Taiwan's ruling bloc's imaginary and real other, covering up many contradictions of gender and class, internally unifying the concept of "Taiwan" and "externally inserting it into the neo-colonial structure of global capitalism led by the American Empire."

In a later essay, through his readings of critical writers but especially those of Fanan, Said, Nandy and a dissident thinker of late 16th century China, Chiao Hung, Chen proposes that "critical syncretism," - both a strategy and an ethics, of "becoming 
others" (the poor, the black, the aborigines, the female, the homosexual) — should be employed for formulating more liberating subjectivity. Only this "downward" direction of moving into the field of social forces in which antagonism and contradiction have already been on the move can ethnocentrism be overcome.

If, according to Chen's allegation, that the ruling bloc in Taiwan attempts to copy experiences of her former coloniser Japan and "ascend" to a sub-imperial status, then we probably can invert the picture and accuse this same ruling bloc of making "audiovisual media imperialism" a reality in Taiwan of 1990s — in contrast to what was accurately portrayed two decades earlier by Chin-Chuan Lee $(1979,165)$ in Media Imperialism Reconsidered that, amid heavy political and economic dependence, Taiwan had resisted "media imperialism" successfully to a substantial degree between 1960s and 1970s since influences of American media were being intentionally suppressed by the Taiwan state. But as in 1993, with the import of audio-visual products at around 400 million US dollars (close to half of Taiwan's market), the thesis of Taiwan as one exception to American media imperialism can no longer be sustained.

Why and how has this transition been taking place, and what is meant by (media) imperialism? In their respective ways, most of the essays compiled in the books edited by Cheng, Jiang and Feng have provided different entries to consider on these issues. I shall focus on my own contributions (Feng 1995) when attending to these questions, while in the meantime I shall note the work and viewpoints from authors appearing in the volumes edited by Cheng and Jiang.

Instead of viewing imperialism as a political phenomenon, as that of dominated relationships between nations, instead of interpreting its origin as "the will to power" of individuals or nations, the imperialist phenomenon is understood as a politicaleconomic order, as co-operative and conflicting relationships among states, transnational capital and local capital. Within this analytic framework, new media (video techniques, cable and satellite) are not perceived as "technologies of freedom," as championed by Ithiel de Sola Pool, but are seen as forces that modify power structures of different units within this imperial formulation. Therefore, since its inception in Taiwan in the early 1980s, these new technologies have gradually lent forces to transnational (in this case, American) capital to expand eroded power of local states to regulate and reduce the profit margins of local capital. And this process may be distinctively divided into two sequences, with local capital winning the upper hand in the first instance while discovering later that they actually had assumed the role of broker in the process of opening up the market for American audio-visual programs.

The first stage can be set as starting from the early 1980s when self-employed people (a number of them owning electronic shops) around the island discovered potential business opportunities and started primitive cable trades, which, very much like larger close-circuit systems, then carried pirated programs, mainly of American and Japanese origins, to subscribers who paid 2-3 dollars per month in exchange for a few channels that provided more entertaining programming than available from the three networks operating under control of the state. Because the programs were pirated, expenses were negligible, which made running a cable business very inexpensive, which in turn enticed more and more families to subscribe to cable. Its existence also provided outlets for viewers to avoid programming on the three state-controlled stations. As such, the presence of cable might have defused or delayed possible challenge to the state's authoritarian and moralistic control over television resources. If such an 
assumption is true, then the state could be said to share a common interest with these "illegal" cable operators, so long as the cable systems did not cross the entertainment line and provide programming on political activities.

However, at least three new conditions gradually emerged to phase out the "golden" decade of small capital profiting on this new but least regulated audio-visual market. To begin, since this market was particularly lucrative, larger domestic capitalists could not avoid supporting it, and this generated conflicts between legal (mostly larger capitalists) and the "illegal" players, resulting in pleas for the state to intervene and regulate the market. In the meantime, political activists opposing the Nationalist rule also made use of cable systems for disseminating their ideas, especially during the election periods. The state, an instrument of the Nationalist government, consequently had a second opportunity to impose control onto the cable communication networks.

Lastly, the world economy was undergoing change, as exemplified by the GATT negotiations in the Uruquay Round (1987-1993). One of the major concerns of these negotiations was discussion of treaties implementing intellectual property rights. Though not a member of this trade organisation, Taiwan had been making effort to join, and since pervasive pirated audio-visual products were doing extensive damage to (predominantly) American's interests, the government, out of obvious pressures from the US State Department, quickly enacted the Cable Act in July 1993.

With more extensive state intervention, the opportunity for Taiwan's smaller capital ventures to survive, not to mention prosper, diminished. ${ }^{4}$ It has been pointed out that the pirate activity during the 1980s cultivated a market for consuming Hollywoodstyle audio-visual programs, ultimately to the benefit of program exporters. As such, it is argued that, in a structural playout and not in any sense as an instrumental conspiracy, new technologies made it possible for American media capital to provide a "free lunch" of pirated programming at an earlier stage and consequently formulate a market for later exploitation. The state of Taiwan had been both voluntarily and forced to step in and cater to the interests of major capital investors. Whether these imperial forces, involving shifting relations between the states, transnational capital and local capital, will produce homogenous patterns of media consumption is a question worth pursuing, but none of the three books reviewed in this essay touches upon this issue. Since similar imperial relationships seem to be surfacing in some of China's major cities like Beijing, Gwangzhou and Shanghai, where pirated audio-visual goods are finding expansive markets, ${ }^{5}$ implications of such a problematic goes beyond Taiwan proper.

The last item reviewed in this essay is important in two senses. It was the only occasion in which Mass Communication Research (launched in 1967), a noted academic journal in the field, invited newspeople of conflicting opinions to write on their experiences with regards to the only autonomous collective action Taiwan's journalists had ever taken in the post-war era.

In the summer 1994 the Independent Post and Independent Evening News were sold to a conglomerate close to the ruling party, which caused an uproar as these two titles, partly for market considerations, had been historically in support of the opposition movement and Taiwanese identity. Journalists, including those from other newspapers, who earlier that year had had already started to meet and discuss possibilities of organising a journalist union across the press (there is no such union in Taiwan) soon took advantage of this incident and called for formulation of a national journalist union, at once advancing ideals of critical journalism and protecting practitioners' work. By 
organising a rally and march, and by winning support from various noted literati and academics, their appeals were relatively well-publicised. In March 1995, six months after the take-over was finalised, Taiwan's Journalists Association (TJA) was set up not as a "union" but as an "association." How different participants assessed the situation and how they acted were analysed in this special issue. My judgement is that TJA was a success in the sense that it has launched the bimonthly journal Media Watch which fulfils a reflective function and provides a public forum for reforming the media. On the other hand, the TJA was a failure in regard to its membership: as of March 1998, three years after conception, there are a mere 400 members.

Between 1987 and 1995, the number of Taiwan's full-time academic workers in the field of journalism and communication grew from 58 to 216, an increase of nearly four-fold, surpassing all other disciplines (e.g., people teaching in law only increased from 127 to 189). This "spectacle" reflects the "marvel" of media explosion during the same period and provides momentum for the publications reviewed in this essay. However, compared to the over 100 communication books translated in Taiwan during the past five years, these publications with a critical edge and local colour are far too few. Before more contributions to communication studies can be expected the Chinese have a long way to go.

\section{Notes:}

1. Taiwan became a territory of Imperial China in the late 16th century and was ceded to Japan between 1895 and 1945. In 1949 the Nationalist Party, defeated and driven out of China by the Communist Party, withdrew to Taiwan and, under auspices of the USA, still claims itself as the only legitimate government of China. Hong Kong had been a colony of the UK between 1842 and 1997. when it was returned to China.

2. Like-minded contributions in Chinese can also be found in two volumes edited by Kuo-jen Tsang (1995), which contain papers presented at the 1993 Conference of Chinese Communication Research and Education held in Taiwan.

3. Some of the works are Journalism and Combination Industries in Seven Countries: France, the USA, Yugoslavia, Mexico, Japan, Russia and the UK, edited by Institute of Journalism, Bejing: Social Science Academy (1986); Contemporary Mass Communication History of Japan: 1945-1990, Shanghai: Xielin (1992).

4. The will and capacity of this small-scale capital to survive should not be dismissed. In late 1993 when the state legalised all existing cable operators, its number stood at 618 , and as in late 1997 , the number was still between 100 and 150 (although two-thirds of which probably have shares owned by the two biggest cable operators).

5. One recent example: prior to its premier in these cities on April 4, 1988, the Hollywood blockbuster Titanic a pirated version on VCD was already widely circulating, which costs Renmienbi 16 dollars; in comparison, a theatre ticket costs 50 dollars.

\section{References:}

Chen, Kuan-hsin. Forthcoming. From Postmodernism to Decolonization. Taipei: Tanshan.

Cheng, Jeh-chen, ed. 1993. Deconstructing Television and Broadcasting Media. Taipei: Taipei Society.

Chu, Godwin C. and Francis L. K. Hsu. 1979. Moving A Mountain: Cultural Change in China. Hawaii:

University Press of Hawaii.

Feng, Chien-san. 1995. For a Political Economy of Taiwan's Television and Broadcasting Industries in the 1990s.Taipei: Tanshan.

Institute of Journalism, ed. 1986. Journalism and Combination Industries in Seven Countries: France, the USA, Yugoslavia, Mexico, Japan, Russia and the UK. Bejing: Social Science Academy. 
Jiang, Wen-yu, ed. 1994. Media Reform, Freedom and Democracy. Taipei: Vanguard.

Lee, Chin-chuan. 1979. Media Imperialism Reconsidered . London: Sage.

Lee, Chin-chuan, ed. 1990. Voice of China: The Interplay of Politics and Journalism. New York: Guilford.

Lee, Chin-chuan, ed. 1994. China's Media, Media's China. Boulder: Westview.

Lee, Chin-chuan, ed. Forthcoming. Money, Power, and Media: Communication Patterns, Bureaucratic Control in Cultural China. Evanston: Northwestern University Press.

Mass Communication Research. 1996. "Newsroom Democracy." Special issue, No. 52 (January).

Taipei: Department of Journalism, Chengchi University.

Taiwan Professors Association (TPA). 1993a. Boycotting the Newspaper to Sustain Taiwan's Independence (I). Taipei: TPA.

Taiwan Professors Association (TPA). 1993b. Boycotting the Newspaper to Sustain Taiwan's Independence (II). Taipei: TPA.

Taiwan Professors Association (TPA). 1994. A Critic of Judgment Upon the Boycott Case. Taipei: TPA.

Zhang, guo-liang. 1992. Contemporary Mass Communication History of Japan: 1945-1990. Shanghai: Xielin.

Tsang, Kuo-jen. 1995a. Journalism and Communication Researches in the Mainland China. Taipei: Chengchi University.

Tsang, Kuo-jen. 1995b. Communication Researches in Chinese Language. Taipei: Chengchi University. 